\title{
DECOLE - Desenvolvendo Competências de Letramento Emergente: propostas integradoras para a pré-escola, de Fernanda Leopoldina Viana, Iolanda Ribeiro e Sylvia Domingos Barrera (orgs.).
}

\author{
Porto Alegre: Penso, 2017.
}

\begin{abstract}
Andreia Menarbini
Doutoranda em Educaçâo pela Universidade Nove de Julho. Professora da Educaçấo Básica na Rede Municipal de Ensino de Santo André e integrante do Grupo de Pesquisa Fundamentos Epistemológicos das Políticas Educacionais (GRUFEPE). andreiamenarbini@gmail.com
\end{abstract}

Fernanda Leopoldina Viana é especialista em Psicologia da Educação pela Ordem dos Psicólogos Portugueses; Mestre e Doutora em Psicologia da Educação pela Universidade do Minho, mesma instituição em que ensina como Professora Associada no Instituto de Educação e do Instituto de Estudos da Criança. Publicou I2 artigos em revistas especializadas e 16 trabalhos em anais de eventos, possui 8 capítulos de livros e in livros publicados, além de 62 itens de produção técnica. Entre I983 e 20 I participou em Is projetos de investigação, sendo que coordenou 6 destes, e recebeu 3 prêmios e/ou homenagens. Atualmente, é diretora adjunta do Centro de Investigação em Estudos da Criança e integrou a Comissão Diretiva do Doutoramento em Estudos da Criança do Instituto de Educação da Universidade do Minho. Atua nas áreas de Ciências Sociais com ênfase em Psicologia e Ciências Sociais e também em Ciências da Educação. Nas suas atividades profissionais interagiu com 4I colaboradores em coautorias de trabalhos científicos. No seu curriculum DeGóis os termos mais frequentes de contextualização de sua produção científica, técnica e artístico-cultural são: Learning, Early literacy, Reading Comprehension, Assessment, Reading, Language, Learning to Read, Lecture, Reading Assessment e Young Children.

Iolanda Ribeiro é especialista em Psicologia da Educação pela Ordem dos Psicólogos Portugueses. Mestre e Doutora em Psicologia da Educação pela Universidade do Minho e Professora Auxiliar no Instituto 
de Psicologia, Departamento de Psicologia Aplicada da Escola de Psicologia dessa mesma universidade. Publicou 20 artigos em revistas especializadas e I 3 trabalhos em anais de eventos, possui I 2 capítulos de livros e is livros publicados, ademais de I64 itens de produçấo técnica. Orientou 2 teses de doutoramento e 23 dissertaçôes de mestrado na área de Psicologia. Atua na área de Ciências Sociais com ênfase em Psicologia e em suas atividades profissionais interagiu com 103 colaboradores em coautorias de trabalhos científicos.

Sylvia Domingos Barrera é graduada em Psicologia pela Universidade de São Paulo (1985), possui mestrado (1995) e doutorado (2000) em Psicologia Escolar e do Desenvolvimento Humano pela Universidade de São Paulo. É Professora do Departamento de Psicologia da Faculdade de Filosofia, Ciências e Letras de Ribeirão Preto da USP (FFCLRP-USP) e compóe o corpo docente do Programa de Pós-graduação em Psicologia da FFCLRP-USP. Tem experiência nas áreas de Psicologia Educacional e Psicologia Cognitiva, atuando principalmente nos seguintes temas: alfabetização, consciência fonológica, habilidades metalinguísticas, dificuldades de aprendizagem, leitura e escrita.

O livro que aqui resenhamos, organizado por essas autoras, expóe o programa Desenvolvendo Competências de Letramento Emergente (DECOLE), destinado às crianças do último ano da Educação Infantil , elaborado por um grupo de pesquisadoras da Universidade do Minho, em Portugal, sob a coordenação das professoras Fernanda Leopoldina Viana e Iolanda Ribeiro (VIANA; RIBEIRO, 20I4), a partir da adaptação brasileira do programa Falar, Ler e Escrever: Propostas Integradoras para Jardim de Infância. O objetivo geral do programa DECOLE é proporcionar, aos educadores da Educação Infantil , um conjunto estruturado de atividades que contribuam para o desenvolvimento das competências de letramento emergente, ou seja, de habilidades, conhecimentos e atitudes considerados facilitadores da aprendizagem da leitura e da escrita, com destaque à linguagem oral, aos conhecimentos a respeito do material impresso, às habilidades de consciência fonológica e morfossintática e à motivação para as atividades de leitura e escrita.

A obra está dividida em cinco capítulos. O capítulo I contextualiza a etapa da Educação Infantil, no Brasil, a partir do histórico das orientaçôes curriculares e da organização estrutural vigentes; apresenta a análise 
crítica das propostas curriculares oficiais e a análise comparativa das semelhanças e diferenças em relação à proposta oficial portuguesa, seguidos por consideraçóes gerais sobre os pressupostos teóricos e as características do programa proposto, incluso o trabalho de adaptaçáo realizado para a elaboração da versão brasileira do programa.

Já no capítulo 2, as autoras apresentam o conceito de letramento emergente, esclarecendo o que se deve entender por desenvolvimento e aprendizagem da linguagem escrita na Educaçáo Infantil, a partir da ampliaçáo do entendimento da presença da língua escrita nessa etapa da educação básica, com a intencionalidade de apoiar e desenvolver, de forma metódica e sistemática, a emergência nas crianças do letramento, nele inclusos os primeiros passos para a alfabetização. Nos capítulos 3 e 4, caracterizam as atividades que contribuem para o desenvolvimento da percepçáo das diferenças entre língua oral e escrita, o enriquecimento do vocabulário infantil, a consciência metalinguística e metacognitiva, a sensibilidade para a língua como um sistema de representação fonológico, morfológico e sintático, a escrita como alternativa de interação. Todas essas atividades são demonstradas no capítulo 5, por meio de roteiros exemplificados de desenvolvimento de letramento emergente, baseados em leituras da literatura infantil brasileira que proporcionam às crianças meios de apropriação de estratégias de compreensão e de interpretação do linguístico e do imagético, a fim de perceberem as diferenças entre linguagem oral e escrita, as sensificando para as particularidades da língua escrita.

Recomenda-se a leitura porque o leitor terá acesso a uma obra incomum para a Educação Infantil do Brasil, já que o livro contribui com um novo conceito, denominado letramento emergente, e aborda propostas práticas pedagógicas para essa etapa de ensino.

Ao tratar do processo histórico, as autoras retomam diferentes concepçôes de Educação Infantil ao longo dos anos e destacam dois importantes marcos de mudança nas políticas para esse nível de ensino: a Constituição de 1988 e a Lei Federal no 9.394/96 que institui as Diretrizes e Bases da Educação Nacional e integra a Educação Infantil na primeira etapa da educação básica brasileira e, consequentemente, origina diversos estudos, diretrizes e açóes que tratam do desenvolvimento e da aprendizagem da criança. Dessa forma, favorecem a compreensão da história dessa etapa do ensino e de sua principal especificidade, que se refere ao processo 
de desenvolvimento humano ser proeminente no trabalho da Educação Infantil, devido às características próprias da faixa etária.

Outra questáo importante em destaque é quanto ao trabalho com a linguagem escrita para as crianças pequenas, o qual provoca divergências entre educadores por diferentes motivos. Entre os argumentos contrários para os que concebem o trabalho com a língua escrita como o ato de ensinar a ler e a escrever, no sentido de alfabetizar, está o de que a alfabetização requer condiçôes cognitivas para a aprendizagem do sistema de representação alfabético, o que as leva a afirmar que crianças de 4 ou 5 anos não estão em condiçóes de aprender.

Também há o esclarecimento de que, com o avanço nos estudos em alfabetizaçáo, surge o conceito de letramento, o qual indica que o processo de alfabetizar é um dos componentes de inserção da criança no mundo letrado, que não só demanda o ler e escrever, mas sim todo o processo de apropriação dos usos e funçóes sociais da escrita, ampliando o significado e as formas de atuação sobre a temática. A compreensão desse conceito é imprescindível aos profissionais que trabalham com a alfabetização.

As autoras, a partir da compreensão de que o letramento emerge desde cedo na vida da criança integrante de uma sociedade letrada, agregam o adjetivo emergente ao letramento quando se refere ao desenvolvimento e aprendizagem das crianças e, assim, criam o conceito em educação do letramento emergente, que é amplamente trabalhado na obra.

Na mesma perspectiva, abordam a Educaçáo Infantil de forma inovadora e fundamentada, justificando uma nova concepçáo da natureza das atividades de inserção da criança no mundo letrado, na primeira etapa da educação básica, que lhes oportunize desenvolver seu letramento emergente por meio de atividades que respeitem e se articulem ao desenvolvimento infantil.

Unindo fundamentos e práticas, inovam na concepção da língua escrita na Educação Infantil ao proporem razóes teóricas e práticas para a inserção das crianças nessa nova concepção de educação, o que pode trazer contribuiçóes importantes para os profissionais da área educacional e na aprendizagem dos alunos.

A leitura do livro promoverá reflexôes teóricas e sobre as práticas da Educação Infantil, que se modificam ao longo dos anos, devido às mudanças sociais, governamentais e econômicas nacionais e dos estudos na área. 